\section{Sulfated fucan from marine alga inhibits HeLa cells infection by HTLV-1 free particles: semi- quantitative analysis}

\author{
Maria T. V. Romanos, ${ }^{, 1}$ Maria J. Andrada-Serpa, ${ }^{2}$ Paulo A. S. \\ Mourão, ${ }^{3}$ Yocie Yoneshigue-Valentin, ${ }^{4}$ Mariana S. Pereira, ${ }^{3}$ \\ Norma Santos, ${ }^{1}$ Marcia D. Wigg ${ }^{1}$
}

${ }^{1}$ Departamento de Virologia, Instituto de Microbiologia Paulo de Góes, Centro de Ciências da Saúde, Universidade Federal do Rio de Janeiro, Brazil,

${ }^{2}$ Instituto de Pesquisa de Clínica Evandro Chagas, IPEC/Fiocruz, Brazil,

${ }^{3}$ Laboratório de Tecido Conjuntivo, Hospital Universitário Clementino Fraga Filho $4{ }^{\circ}$ andar, Universidade Federal do Rio de Janeiro, Brazil.

${ }^{4}$ Departamento de Botânica, Instituto de Biologia, Universidade Federal do Rio de Janeiro, Brazil.

\begin{abstract}
A sulfated fucan from Laminaria abyssalis marine alga prevented the interaction of HTLV-1 particles, purified from the MT-2 cell line, with HeLa cells. The infection obtained using a concentrated virus suspension was detected only by amplification of the newly synthesized HTLV-1 proviral cDNA by the nestedpolymerase chain reaction (PCR). The sulfated polysaccharide was not toxic to the cells at a concentration of $100 \mu \mathrm{g} / \mathrm{mL}$ and prevented infection by the viral particles when added to the cell monolayers. The proviral cDNA was only detected when the sulfated polysaccharide was added to the cells three hours post-infection, indicating that the inhibitory activity occurred in the initial stages of virus-cell interaction. Our results demonstrate, for the first time, the ability of a sulfated fucan from marine algae to inhibit virus transmission through free virus particles.
\end{abstract}

Revista Brasileira de Farmacognosia Brazilian Journal of Pharmacognosy 21(2): 229-233, Mar./Apr. 2011

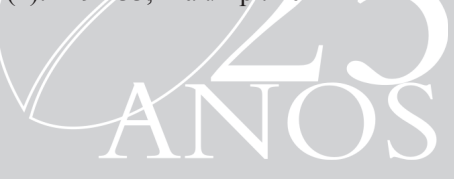

\section{Article}

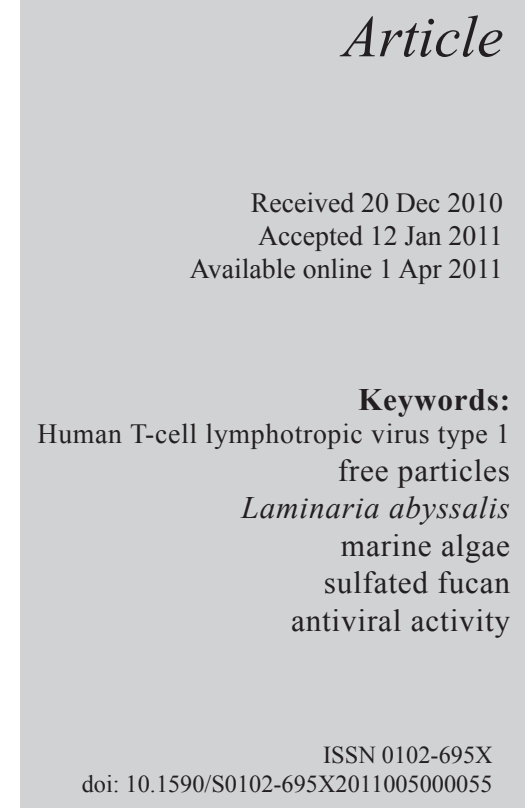

\section{Introduction}

The human T-cell lymphotropic virus type 1 (HTLV-1) was initially identified by Poiesz et al. (1980) and has been associated with a hematopoietic malignancy, adult T-cell leukemia/lymphoma (ATLL), and with a degenerative neurologic disorder called tropical spastic paraparesis or human T-cell lymphotropic type 1-associated myelopathy (TSP/ HAM). Prognosis of adult T-cell leukemia/lymphoma remains poor because of immunosuppression and intrinsic resistance to chemotherapy.

Treatment of ATLL with a combination of zidovudine (AZT) and interferon-alpha (IFN) prolongs the survival of patients (Bazarbachi \& Hermine, 2001). In spite of this success, the search for new anti-retroviral agents with different mechanisms of action is encouraged.

Sulfated polysaccharides obtained from marine algae have been shown to inhibit the propagation of different viruses, including HTLV-1. The mechanism by which these polysaccharides exert an antiviral effect can be attributed to interference in the virus binding to cell receptors (Witvrouw \& De Clercq, 1997). Furthermore, Ida et al. (1994) and Romanos et al. (2002a) have also shown that sulfated polysaccharides are able to inhibit cell-to-cell contact, essential for HTLV-1 transmission.

Cell-to-cell contact is needed for effective infection with HTLV-1 (Miyoshi et al., 1981; Yamamoto et al., 1982; Popovic et al., 1983; Delamarre et al., 1997; Lairmore \& Franchini, 2007). However infection with free virus particles has also been described in vitro (Clapham et al., 1983; Hoxie et al., 1984; Trejo \& Ratner, 2000).

In this study we report that a sulfated fucan from the Laminaria abyssalis marine alga inhibits HeLa cells infection by free HTLV-1 particles in vitro.

\section{Materials and Methods}

Cells and virus

HTLV-I infected T-cell line MT-2 (established cell line from umbilical cord lymphocytes transformed by HTLV-1 following co-cultivation with leukemialymphoma cells) and non-infected cell line HeLa (human cervical carcinoma) were maintained in RPMI 1640 (Sigma) supplemented with $2 \mathrm{mM}$ L-glutamine (Sigma), $50 \mu \mathrm{g} / \mathrm{mL}$ garamicin (Shering-Plough), and 2.5 $\mu \mathrm{g} / \mathrm{mL}$ fungizon (Gibco) plus $10 \%$ of heat-inactivated fetal bovine serum (FBS) (Cultilab) and maintained at 
$37^{\circ} \mathrm{C}$ in atmosphere of $5 \%$ of $\mathrm{CO}_{2}$.

\section{Sulfated polysaccharide from marine algae}

Laminaria abyssalis A. B. Joly \& E. C. Oliveira (Phaeophyta) marine alga, a brown seaweed, was collected from $60 \mathrm{~m}$ depth of Macaé City at $\left(22^{\circ}\right.$ 30'S; 40 59'W), Rio de Janeiro State, Brazil. After collection the algae were kept alive until arrival at the laboratory. A voucher of this specimen has been deposited in the Botany Department, Biology Institute, Federal University of Rio de Janeiro, Brazil. The polysaccharide was extracted from the dried alga by papain digestion and the sulfated fucan was purified by $N$-cetyl- $N, N, N$-trimethilammonium bromide and ethanol precipitations, followed by anion-exchange chromatography on DEAE-cellulose, as previously described (Pereira et al., 1999). The purity of the sulfated fucan was evaluated by chemical analysis, agarose gel electrophoresis and ${ }^{1} \mathrm{H}-\mathrm{NMR}$ spectra, as described (Pereira et al., 1999).

\section{Cytotoxicity assays}

The cytotoxicity of the sulfated fucan to HeLa cells was assessed via the in situ reduction of 3-(4,5-dimethylthiazol-2-yl)-2,5-diphenyltetrazolium bromide (MTT) (Sigma) to blue formazan by mitochondrial dehydrogenases of metabolically active cells. HeLa cell confluent monolayers $\left(2 \times 10^{5}\right.$ cells/ $\mathrm{mL}$ ), cultivated in 96-well flat-bottomed plates, were incubated in the presence of the sulfated fucan at different concentrations. After $24 \mathrm{~h}, 20 \mu \mathrm{L}$ of MTT ( $7.5 \mathrm{mg} / \mathrm{mL}$ in phosphate-buffered saline, $\mathrm{pH}$ 7.2) was added to each well and the cell cultures were incubated for $5 \mathrm{~h}$ at $37^{\circ} \mathrm{C}$. Solubilization of the formazan crystals was achieved by adding $100 \mu \mathrm{L}$ of $0.4 \% \mathrm{HCl}$ and $10 \%$ Triton X-100 in isopropanol. The absorbance was read in a spectrophotometer (Bio-Rad Model 3550-UV) at a wavelength of $595 \mathrm{~nm}$ (Romanos et al., 2002b).

\section{Concentration and purification of virus particles}

The viral suspension was obtained from the growth media of the virus-producing cell line MT-2. The cell suspension containing HTLV-1 particles was clarified by centrifugation (Sorval RC5-B - rotor HS-4) at 6,500 $\mathrm{g}$ for $30 \mathrm{~min}$ and the supernatant was concentrated by ultracentrifugation (Beckman LE 80K, rotor Beckman $45 \mathrm{ti}$ ) at 30,000 $\mathrm{g}$ for $2 \mathrm{~h}$ in $17 \%$ sucrose cushion. The pellet was resuspended to 1:100 (in relation to the original volume of virus suspension) in TNE buffer $(20 \mathrm{mM}$ Tris/HCl, $100 \mathrm{mM} \mathrm{NaCl}, 1 \mathrm{mM}$ EDTA, pH7.5). HTLV-1 was purified by ultracentrifugation (Beckman LE 80K, rotor Beckman SW40) through a
20 to $60 \%$ sucrose gradient at $100,000 \mathrm{~g}$ for $18 \mathrm{~h}$.

\section{Detection of the purified virus}

Before carrying out the cell-free infection assay, a RT-PCR assay was performed for detection of the HTLV-1 particles in the virus preparation. RNA was extracted from the purified virus suspension in Catrimox14 solution (Iowa Biotechnology Corp., Coralville, IA) following the manufacturer's specification with minor modification. Two hundred microliters Purified virus suspension $(200 \mu \mathrm{L})$ were added to $1 \mathrm{~mL}$ of Catrimox14. After centrifugation (Heraeus Instruments Microcentrifuge) at $1,000 \mathrm{~g} / 5 \mathrm{~min}$, the supernatant was discarded and the pellet was resuspended in $500 \mu \mathrm{L}$ of $2 \mathrm{M}$ lithium chloride. The mixture was centrifuged $(1,000 \mathrm{~g} / 5 \mathrm{~min})$, the supernatant was discarded, and the pellet was washed in $70 \%$ ethanol and solubilized in deionized water. The RNA from MT-2 cell was also extracted using the same procedure.

To discard the possibility of DNA contamination, the extracted RNA was treated with 500 $\mathrm{U} / \mathrm{mL}$ DNase (Pharmacia) for $2 \mathrm{~h}$.

The purified RNA was assayed by RT-PCR. RNA $(10 \mu \mathrm{L})$ were added to PCR tubes containing $7 \mu \mathrm{L}$ dimethylsulfoxide (Sigma) and denatured at $97{ }^{\circ} \mathrm{C}$ for $5 \mathrm{~min}$. The suspension was then cooled in ice for $5 \mathrm{~min}$ and the following reaction mixture was added: $52 \mu \mathrm{L}$ water; $16 \mu \mathrm{L}$ deoxynucleoside triphosphate mixture (containing $1.25 \mathrm{mM}$ each of dATP, dGTP, dCTP, and dTTP [Life Technologies]); $10 \mu \mathrm{L} \mathrm{10x}$ buffer (containing $200 \mathrm{mM}$ Tris-HCl, pH8.4, $500 \mathrm{mM} \mathrm{KCl} \mathrm{[Life} \mathrm{Technologies]);} 3 \mu \mathrm{L} 50$ $\mathrm{mM} \mathrm{MgCl}_{2}$ (Life Technologies); $1 \mu \mathrm{L}$ of primers (containing $50 \mathrm{pmol} / \mu \mathrm{L}$ each of SK43 (+) (5'CGGATACCCAGTCTACGTGT-3') and SK44 (-) (5'-GAGCCGATAACGCGTCCATCG-3'); 2.5 units of Taq DNA polymerase (Life Technologies); and 3.3 units of reverse transcriptase (AMV-RT [Molecular Genetic Resources]). The mixture was incubated at $42{ }^{\circ} \mathrm{C}$ for $45 \mathrm{~min}$ for reverse transcription, followed by an incubation of $94{ }^{\circ} \mathrm{C} / 5 \mathrm{~min}$, and submitted to 35 cycles of PCR $\left(1 \mathrm{~min}\right.$. at $94{ }^{\circ} \mathrm{C}, 30 \mathrm{~s}$ at $60{ }^{\circ} \mathrm{C}, 30$ $\mathrm{s}$ at $70{ }^{\circ} \mathrm{C}$ ), and a final $7 \mathrm{~min}$ incubation at $68{ }^{\circ} \mathrm{C}$. The primers amplified a 159-bp segment from the pX gene.

Amplified DNA fragments were submitted to Nested-PCR. PCR products $(5 \mu \mathrm{L})$ were added to PCR tubes containing $7 \mu \mathrm{L}$ DMSO and $88 \mu \mathrm{L}$ of the reaction mixture were added: $57 \mu \mathrm{L}$ water; $16 \mu \mathrm{L}$ deoxynucleoside triphosphate mixture (containing $1.25 \mathrm{mM}$ each of dATP, dGTP, dCTP, and dTTP [Life Technologies]); $10 \mu \mathrm{L} \mathrm{10x}$ buffer (containing $200 \mathrm{mM}$ Tris-HCl, pH8.4, 500 mM KCl [Life Technologies]); $3 \mu \mathrm{L} 50 \mathrm{mM} \mathrm{MgCl}_{2}$ (Life Technologies); $1 \mu \mathrm{L}$ of 
primers (containing $40 \mathrm{pmol} / \mu \mathrm{L}$ each of $\mathrm{TN} 1(+)$ (5'-ACGTGTTTGGCGATTGTGT-3') and TN2 (-) (5'-CATCGATGGGGTCCCAGGTGA-3'); 2.5 units of Taq DNA polymerase (Life Technologies)). PCR was performed as described above. The primers amplified a 129-bp segment.

PCR products $(10 \mu \mathrm{L})$ were loaded on $1.2 \%$ agarose gel in TBE buffer (44.5 mM Tris, $44.5 \mathrm{mM}$ boric acid, 1 mM EDTA, pH 8.0). The electrophoresis was performed at $120 \mathrm{~V}$ for $1 \mathrm{~h}$ in $0.5 \mathrm{X}$ TBE buffer containing $0.5 \mu \mathrm{L}$ of ethidium bromide $/ \mathrm{mL}$.

\section{Antiviral assay}

HeLa cells monolayers $\left(10^{6}\right.$ cells $\left./ \mathrm{mL}\right)$ were infected with $400 \mu \mathrm{L}$ of purified HTLV-1 suspension and sulfated fucan $(100 \mu \mathrm{g} / \mathrm{mL})$ added at different times $(0,1,2$ and 3 h) after infection. Four hours after infection, cell monolayers were washed three times and the DNA was extracted in DNAzol reagent (Life Technologies) following the manufacturer's specification. Five hundred microliters of DNAzol reagent were added to the cell monolayer, and the DNA was precipited by the addition of $250 \mu \mathrm{L}$ of $100 \%$ ethanol. The sample was mixed by inversion, stored at room temperature for $3 \mathrm{~min}$. and centrifuged (Heraeus Instruments Microcentrifuge) for $10 \mathrm{~min}$. at 2,500 g. The pellet was washed in $70 \%$ ethanol and solubilized in deionized water. The sample obtained was analysed for HTLV-1 proviral DNA by PCR and Nested-PCR as above described.

\section{Results}

Initially we tested whether algal sulfated fucan is toxic to HeLa cells. The cells were exposed to a high concentration of the sulfated fucan $(100 \mu \mathrm{g} / \mathrm{mL})$ and no cytotoxicity was observed, as indicated by in situ assay of reduction of MTT to blue formazan by mitochondrial dehydrogenases of metabolically active cells (not shown).

Subsequently, we purified the virus particles from the growth media of the virus-producing cell line MT-2. RT-PCR was carried out to detect viral RNA in a purified HTLV-1 suspension. After RT-PCR, the cDNA was detected only on virus harvested from MT-2 cells. To detect the cDNA from purified virus suspensions, the RT-PCR product was submitted to nested-PCR (Figure 1).

Finally, we evaluated the antiviral activity of the sulfated fucan. For this experiment, $400 \mu \mathrm{L}$ of purified virus suspension were added to HeLa cells monolayers. Sulfated fucan was added to the cell cultures at different times after the infection.

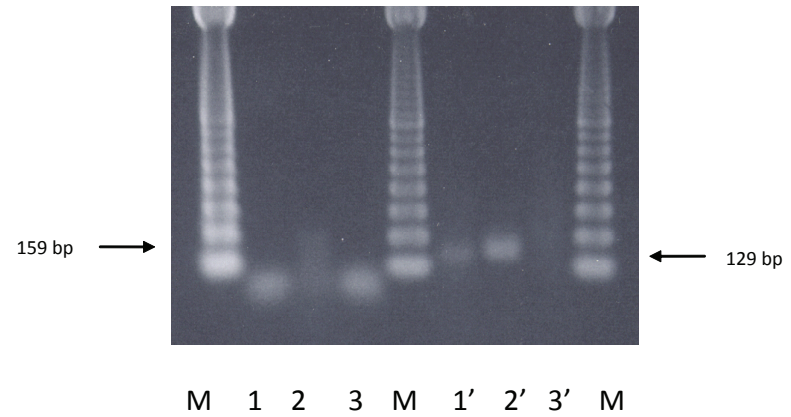

Figure 1. RT-PCR and Nested-PCR for detection of HTLV-1 in the purified virus suspension. RNA extracted from the purified HTLV-1 suspension and HTLV-1-producing MT-2 cell were submitted to RT-PCR (lanes 1-3) and Nested-PCR (lanes 1'-3'). Amplified products were observed in agarose gel. Molecular markers (M); RNA from purified HTLV-1 (lanes 1 and 1'); RNA from HTLV-1-producing MT-2 cell (lanes 2 and 2') and; Blank (lanes 3 and 3').

The inhibitory effect of virus infection was evaluated by PCR and Nested-PCR to detect the cDNA, as an indicator of cellular infection by the virus. Figure 2 shows that no cDNA was detected when the sulfated polysaccharide was added up to 2 hours post-infection, indicating that the inhibitory activity occurred in the initial stages of virus-cell interaction, possibly during adsorption and/or penetration of the virus into the cells.

\section{Discussion}

The antiviral effect of sulfated polysaccharides has been associated with their capability to prevent the interaction between molecules present on the surface of the virus and cellular receptors (Nakashima et al., 1989; Baba et al., 1990; Ida et al., 1994; Witvrouw et al., 1994; Sekine et al., 1995; Hayashi et al., 1996; Romanos et al., 2002b; Matsuhiro et al., 2005; Talarico et al., 2005; Adhikari et al., 2006). In a previous study, we demonstrated that a sulfated fucan from the marine alga Laminaria abyssalis was able to inhibit the interaction between HTLV-1 infected cells and indicator cells, avoiding the syncytium formation, essential for an efficient virus infection (Romanos et al., 2002a).

Infection with cell-free HTLV-1 particles is less efficient compared to cell to cell transmission. Nevertheless this mode of transmission may be relevant under particular situations. In fact, in this study we observed that free-particles of the virus induced infection in vitro, although a high viral load was necessary. The infection obtained using a concentrated virus suspension was detected only by amplification of the proviral cDNA by nested-PCR.

We also evaluated the capacity of a sulfated fucan to prevent the interaction of HTLV-1 particles 
with surface cellular receptors. The sulfated fucan was added at different times after infection. Four hours after infection, the cellular DNA was extracted and the HTLV-1 proviral cDNA was analyzed. Our results confirmed that the sulfated fucan from L. abyssalis was able to inhibit the initial stages of the viral infection.

The results presented here demonstrate, for the first time, the ability of a sulfated fucan from marine alga to inhibit virus transmission through free virus particles.

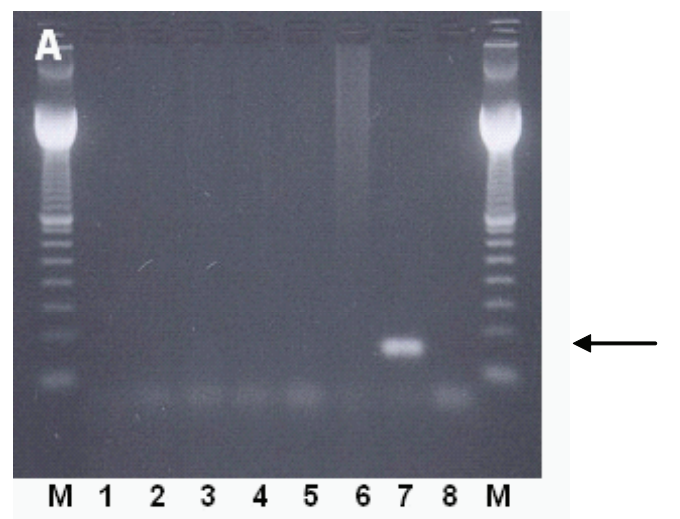

$159 \mathrm{bp}$

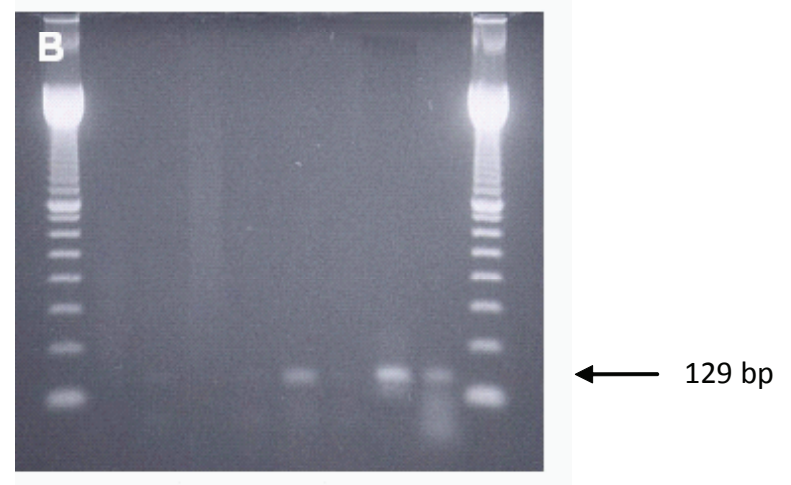

M 1' 2, 3, 4, 5, 6, 7', 8' M

Figure 2. cDNA detection in HTLV-1 infected HeLa cells in the presence of the sulfated fucan. HTLV-1 infected HeLa cells were treated with the sulfated fucan at different times $(0,1$, 2 and $3 \mathrm{~h}$ ) after infection. After $4 \mathrm{~h}$, the cDNA was extracted and detected by PCR (A) and Nested-PCR (B). Molecular markers (M); HeLa cell (Negative Control) (lanes 1 and 1'); HTLV-1 infected HeLa cell in the presence of sulfated fucan at $0 \mathrm{~h}$ (lanes 2 and 2'); after $1 \mathrm{~h}$ (lanes 3 and 3'); after $2 \mathrm{~h}$ (lanes 4 and $4^{\prime}$ ); after $3 \mathrm{~h}$ (lanes 5 and 5'); Blank (lanes 6 and 6'); cDNA from MT-2 cell (positive control) (lanes 7 and 7'); HTLV-1 infected HeLa cell without treatment (lanes 8 and $\left.8^{\prime}\right)$.

\section{Acknowledgments}

We thank Soluza dos Santos Gonçalves for technical assistance. This study was supported in part by the Conselho Nacional de Desenvolvimento Científico e Tecnológico, Coordenação de Aperfeiçoamento de Pessoal de Nível Superior and Fundação Carlos Chagas de Amparo à Pesquisa do Estado do Rio de Janeiro, Brazil.

\section{References}

Adhikari U, Mateu CG, Chattopadhyay K, Pujol CA, Damonte EB, Ray B 2006. Structure and antiviral activity of sulfated fucans from Stoechospermum marginatum. Phytochemistry 67: 2474-2482.

Baba M, Schols D, De Clercq E, Pauwels R, Nagy M, GyörgyiEdelényi J, Löw M, Görög S 1990. Novel sulfated polymers are highly potent and selective inhibitors of human immunodeficiency virus replication and giant cell formation. Antimicrob Agents Chemother 34: 134-138.

Bazarbachi A, Hermine O 2001. Treatment of adult T-cell leukaemia/lymphoma: current strategy and future perspectives. Virus Res 78: 1-4.

Clapham P, Nagy K, Cheingsong-Popov R, Exley M, Weiss RA 1983. Productive infection and cell-free transmission of human T-cell leukemia virus in a nonlymphoid cell line. Science 222: 1125-1127.

Delamarre L, Rosenberg AR, Pique C, Pham D, Dokhélar M-C 1997. A novel human T-leukemia virus type 1 cell-to-cell transmission assay permits definition of SU glycoprotein amino acids important for infectivity. $J$ Virol 71: 259-266.

Hayashi K, Hamada J, Hayashi TA 1996. Screening strategy for selection of anti-HSV-1 and anti-HIV extracts from algae. Phytother Res 10: 233-237.

Hoxie JA, Matthews DM, Clines DB 1984. Infection of human endothelial cells by human T-cell leukemia virus type I. Proc Natl Acad Sci USA 81: 7591-7595.

Ida H, Kurata A, Eguchi K, Yamashita I, Nakashima M, Sakai M, Kawabe Y, Nakamura T, Nagataki S 1994. Mechanism of inhibitory effect of dextran sulfate and heparin on human T-cell lymphotropic virus type I (HTLV-I) - induced syncytium formation in vitro: role of cell-to-cell contact. Antiviral Res 23: 143-159.

Lairmore MD, Franchini G 2007. Human T-cell Leukemia Virus Types 1 and 2. In Knipe DM, Howley PM, Griffin DE, Lamb RA, Martin MA, Roizman B, Straus SE. Fields Virology Philadelphia: Wolters Kluwer Health/Lippincott, Williams and Wilkins 5 ed, vol 2, p. 2071-2105.

Matsuhiro B, Conte AF, Damonte EB, Kolender AA, Matulewicz MC, Mejias EG, Pujol CA, Zuniga EA 2005. Structural analysis and antiviral activity of a sulfated galactan from the red seaweed Schizymenia binderi (Gigartinales, Rhodophyta). Carbohydr Res 340: 2392-2402.

Miyoshi I, Yoshimoto I, Kubonishi H, Taguchi Y, Shiraishi Y, Ohtsuki Y, Akagi T 1981. Transformation of normal human cord lymphocytes by co-cultivation with a lethally irradiated human T-cell line carrying type C virus particles. Gann 72: 997-998.

Nakashima H, Yoshida O, Baba M, De Clercq E, Yamamoto $\mathrm{N}$ 1989. Anti-HIV activity of dextran sulfate as determined under different experimental conditions. Antiviral Res 11: 233-246.

Pereira MS, Mulloy B, Mourão PAS 1999. Structure and 
anticoagulant activity of sulphated fucans. Comparision between the regular, repetitive, and linear fucan from echinoderms with the more heterogeneous and branched polymers from brown algae. $J$ Biol Chem 274: 76567667.

Poiesz BJ, Ruscetti FW, Gazdar AF, Bunn PA, Minna JD, Gallo RC 1980. Detection and isolation of type C retrovirus particles from fresh and cultured lymphocytes of a patient with cutaneous T-cell lymphoma. Proc Natl Acad Sci USA 77: 7415-7419.

Popovic M, Lange-Wantzin G, Sarin PS, Mann D, Gallo RC 1983. Transformation of human umbilical cord blood $\mathrm{T}$ cells by human T-cell leukemia/lymphoma virus. Proc Natl Acad Sci USA 80: 5402-5406.

Romanos MTV, Andrada-Serpa MJ, Mourão PAS, YoneshigueValentin Y, Costa SS, Pereira MS, Miranda MMFS, Gonçalves JLS, Wigg MD 2002a. A sulphated fucan from the Laminaria abyssalis inhibits the human T cell lymphotropic virus type 1-induced syncytium formation in HeLa cells. Antiviral Chem Chemoth 13: 219-221.

Romanos MTV, Andrada-Serpa MJ, Santos MGM, Ribeiro ACF, Yoneshigue-Valentin Y, Wigg MD 2002b. Inhibitory effect of extracts of Brazilian marine algae on human T-cell lymphotropic virus type 1 (HTLV-1) induced syncytium formation in vitro. Cancer Invest 20: 46-54.

Sekine H, Ohonuki N, Sadamusu K, Monma K, Kudoh Y, Nakamura H, Okada Y, Okuyama T 1995. The inhibitory effect of the crude extract from a seaweed of Digenea simplex C. Agardh on the in vitro cytopathic activity of HIV-1 and it's antigen production. Chem Pharm Bull 43: 1580-1584.
Talarico LB, Pujol CA, Zibetti RG, Faria PC, Noseda MD, Duarte ME, Damonte EB 2005. The antiviral activity o sulfated polysaccharides against dengue virus is dependent on virus serotype and host cell. Antiviral Res 66: 103-110.

Trejo SR, Ratner L 2000. The HTLV-I receptor is a widely express protein. Virology 268: 41-48.

Witvrouw M, De Clercq E 1997. Sulfated polysaccharides extracted from sea algae as potential antiviral drugs. Gen Pharmac 29: 497-511.

Witvrouw M, Este JA, Mateu MQ, Reymen D, Andrei G, Snoeck R, Ikeda S, Pauwels R, Bianchini NV, Desmyter J, De Clercq E 1994. Activity of sulfated polysaccharide extracted from the red seaweed Aghardhiela tenera against human-immunodeficiency-virus and other enveloped viruses. Antiviral Chem Chemother 5: 297 303.

Yamamoto N, Okada M, Koyanagi Y, Kannagi M, Hinuma Y 1982. Transformation of human leukocytes by cocultivation with an adult $\mathrm{T}$ cell leukemia virus producer cell line. Science 217: 737-739.

\section{*Correspondence}

Maria T. V. Romanos

Departamento de Virologia, Instituto de Microbiologia Paulo de Góes, Centro de Ciências da Saúde, Universidade Federal do Rio de Janeiro

Cidade Universitária, 21941-590 Rio de Janeiro-RJ, Brazil

teresa.romanos@micro.ufrj.br

Tel. + $55212562-6749$

Fax:+ $55212560-8028$ 